Marquette University

e-Publications@Marquette

Chemistry Faculty Research and Publications

Chemistry, Department of

7-15-2012

Spectroelectrochemical Elucidation of the Kinetics of Two Closely Spaced Electron Transfers

Robert L. Keesey

Marquette University

Michael D. Ryan

Marquette University, michael.ryan@marquette.edu

Accepted version. Journal of Electroanalytical Chemistry, Vol. 667-680, No. 15 (July 2012): 56-62.

DOI. (C) 2012 Elsevier. Used with permission. 


\title{
Spectroelectrochemical Elucidation of the Kinetics of Two Closely Spaced Electron Transfers
}

\author{
Robert L. Keesey \\ Chemistry Department, Marquette University \\ Milwaukee, WI \\ Michael D. Ryan \\ Chemistry Department, Marquette University \\ Milwaukee, WI
}

\begin{abstract}
The use of spectroelectrochemistry to facilitate the analysis of an EE mechanism was reported in this work. Using a set of spectra as a function of potential, the spectra of all three oxidation states were determined using evolving window factor analysis. From these spectra, the concentration of each species in solution was determined for each potential. Using these data, the current was calculated. Unlike the direct measurement of current, the current due to each redox process was determined, allowing one to analyze each redox process separate from the other. With the use of the ButlerVolmer equation, the redox potential and the heterogeneous electron transfer parameters were measured. The spectrally determined current has the advantage of determining the current due to each redox process which is not generally possible with voltammetric data when the redox potentials are close together. This method was applied to the spectroelectrochemical reduction of Escherichia coli sulfite reductase hemoprotein (SiR-HP) in a phosphate buffer and in the presence of cyanide. The electrochemical parameters $\left(E^{\circ} s, k^{\circ} s\right.$ and $a^{\prime} s$ ) for each electron transfer were calculated for both the uncoordinated and cyanide coordinated species. The rates of electron transfer for the siroheme and iron-sulfur cluster were slower than the rates observed for
\end{abstract}


NOT THE PUBLISHED VERSION; this is the author's final, peer-reviewed manuscript. The published version may be accessed by following the link in the citation at the bottom of the page.

other heme proteins. This is probably due to the fact that this protein is significantly larger than most of the heme protein previously studied. This approach is a powerful tool for two-electron transfers when the $E^{\circ}$ values are close together.

Keywords: E. coli; Sulfite reductase hemoprotein; Spectroelectrochemistry; EE mechanism; Quasireversible; Factor analysis

\section{Introduction}

The analysis of multi-electron transfer processes has attracted considerable interest from electrochemists over many decades. A recent review has highlighted the issues involved in the EE mechanism [1]. The question of a single two-electron process versus stepwise mechanism was also addressed by Gileadi [2]. Regardless of the mechanistic and structural issues involved, the experimental deconvolution of individual steps in the EE mechanism can be difficult if the redox potentials are similar. This process can be quite challenging when only current-voltage data are used [3] and [4], because it is difficult to separate the total current into the two redox processes. The problem can be greatly simplified if the currents due to each redox process are separated and solved individually. Spectroelectrochemistry enables this to be done [5] and [6]. The second advantage of this approach is that concentrations of proteins are generally not very high, and separation of the faradaic current from the background can be difficult. Bancroft et al. [7] and [8] have shown the morphological equivalence between the derivative of the absorbance/potential curves and the voltammetric current and have applied this approach to cytochrome $c$. This method was also used to great advantage in studies of myoglobin and cytochrome $c$ [9] and [10]. In this work we have extended this approach to multielectron transfer proteins where it is necessary to calculate the species concentration rather than use select wavelengths because it is, in general, difficult to find a single wavelength that corresponds to only one species.

The redox system that will be examined in this study is Escherichia coli sulfite reductase hemoprotein, which catalyzes the sixelectron reduction of bisulfite to sulfide [11]. In vitro, sulfite reductases are also capable of the reduction of nitrite to ammonia [12]. NADPH-sulfite reductase can be isolated from E. coli $\mathrm{B}$ and

Journal of Electroanalytical Chemistry, Vol. 667-680, No. 15 (July 15, 2012): pg. 56-62. DOI. This article is (C) Elsevier and permission has been granted for this version to appear in e-Publications@Marquette. Elsevier does not grant permission for this article to be further copied/distributed or hosted elsewhere without the express permission from Elsevier. 
consists of twelve protein chains [13] and [14]. The eight flavoprotein chains bind a total of four FAD and four FMN groups. From the DNA sequence, the calculated molecular mass of the flavoprotein is 66,396 Da. The other four protein chains are hemoproteins (SiR-HP), which have a siroheme and an iron-sulfur (4Fe-4S) cluster. The hemoprotein has an apparent molecular mass of 63,000 Da. The crystal structure of the trypsin cleaved and fully oxidized SiR-HP has been obtained [15]. In the fully oxidized crystallized enzyme, the siroheme is coordinated to phosphate ion.

The SiR-HP enzyme can be photoreduced with $5^{\prime}$-deazaflavin and EDTA by two-electrons. The reduction can be written in two oneelectron steps (Reactions (1) and (2)):

$$
\begin{aligned}
& \mathrm{SiR}-\mathrm{HP}^{0}+\mathrm{e}^{-} \rightarrow \mathrm{SiR}-\mathrm{HP}^{-} \\
& \mathrm{SiR}-\mathrm{HP}^{1-}+\mathrm{e}^{-} \rightarrow \mathrm{SiR}-\mathrm{HP}^{2-}
\end{aligned}
$$

where SiR-HP ${ }^{0}$ is the fully oxidized enzyme (ferrisiroheme, [4Fe$4 \mathrm{~S}^{2+}$ ), SiR-HP${ }^{1-}$ is the siroheme reduced enzyme (ferrosiroheme, $[4 \mathrm{Fe}-4 \mathrm{~S}]^{2+}$ ), and $\mathrm{SiR}-\mathrm{HP}^{2-}$ is the fully reduced enzyme (ferrosiroheme, $[4 \mathrm{Fe}-4 \mathrm{~S}]^{+}$). Upon reduction the visible bands of the fully oxidized enzyme at 388, 547, 591 and $714 \mathrm{~nm}$ are shifted to 397 and $608 \mathrm{~nm}$, with two sets of isosbestic points [16]. The redox potential of the first reduction was found to be $-340 \mathrm{mV}$ vs. NHE [17], while the second reduction potential was found to be $-405 \mathrm{mV}$ [16] and [18]. Because the redox potentials of the two electron transfers are close together, there was no potential region where only the intermediate oxidation state (SiR-HP ${ }^{1-}$ ) was observed. The cyanide ligated SiR-HP has a reduction potential of $-155 \mathrm{mV}$ for the siroheme and $-490 \mathrm{mV}$ for the cluster [18].

Previous work has shown that the SiR-HP enzyme can be directly reduced at a methyl viologen modified gold minigrid electrode [19] and [20]. The electron transfer was monitored using visible spectroscopy, and the reduced enzyme was completely recovered when the applied potential was sufficiently positive. We have previously reported on the use of evolving factor analysis to 
deconvolute the spectra and obtain the spectrum of SiR-HP ${ }^{1-}[19]$. From the deconvoluted spectra, the concentrations of the SiR-HP species were obtained at each potential. Preliminary work on the conversion of the concentration data to current has been presented [6].

The use of spectroelectrochemistry to study redox enzymes continues to be an active area of research. With the use of a fluorescently labeled enzyme, Krzeminski et al. [21] were able to show differences in intramolecular and interfacial electron transfer of a nitrite reductase at rest and during turnover. Pita et al. [22] have studied the direct heterogeneous electron transfer reactions of fungal laccases at bare and modified gold electrodes. Jain et al. [23] utilized visible spectrochemistry to characterize Geobacter sulfurreducens biofilms in an optically transparent indium oxide electrode. A novel $c$ type heme enzyme (SoxXA), which contains multiple hemes, was examined by visible spectroelectrochemistry [24]. Mechanism of electron transfer and subsequent reduction in nitrite is still under investigation for copper containing nitrite reductases [25] and the siroheme containing enzymes [26] which can catalyze the reduction of both nitrite and sulfite. Because of the interest in the direct reduction of multi-electron transfer enzymes, studies were carried out and reported in this work that show how the heterogeneous electron transfer parameters can be determined in the case where the potential of individual electron transfer steps are close together. While the focus of this work is an enzymatic system, this approach can be used for any EE mechanism where each species has a unique spectrum.

\section{Experimental}

\subsection{Chemicals and protein isolation}

The distilled water was passed through a Sybron-Barnstead deionizer to a resistivity of $17 \mathrm{M} \Omega / \mathrm{cm}$. The pBR322 plasmid and $E$. coli $B$ were purchased from Promega. The details of the isolation, the assays used and the sources of the chemicals have been previously described [19].

Journal of Electroanalytical Chemistry, Vol. 667-680, No. 15 (July 15, 2012): pg. 56-62. DOI. This article is (C) Elsevier and permission has been granted for this version to appear in e-Publications@Marquette. Elsevier does not grant permission for this article to be further copied/distributed or hosted elsewhere without the express permission from Elsevier. 
NOT THE PUBLISHED VERSION; this is the author's final, peer-reviewed manuscript. The published version may be accessed by following the link in the citation at the bottom of the page.

\subsection{Equipment and procedures}

All spectra were obtained with a Hewlett-Packard 8452A diode array spectrophotometer. The inlet and outlet light path openings in the sample compartment were sealed with microscope cover slips. The sample compartment was sealed from the ambient air with a plastic glove bag. Cooled dry dinitrogen was passed into the sample compartment to maintain the temperature at $10^{\circ} \mathrm{C}$. The dinitrogen also helped maintain anaerobic conditions. The spectroelectrochemical cell was a gold minigrid on which methyl viologen was polymerized. The details of the construction and the procedure for introducing the sample into the cell have been previously described [19]. The potential was maintained by a Cypress Omni 90 potentiostat, and the voltammetric current was manually recorded. For the spectroelectrochemical analysis, a $200 \mu \mathrm{L}$ aliquot of SiR-HP was thawed over ice. A syringe needle ( $22 \mathrm{G} \times 0.75 \mathrm{in}$.) was inserted into the inlet port of the OTTLE cell and sealed using hot silicone glue. The construction and performance of this OTTLE cell containing a methyl viologen modified gold minigrid was described by Ryan and Crawford [20]. As an auxiliary electrode, a platinum syringe needle (Type KF722 plat; Hamilton Co.) was inserted in the outlet port and sealed with hot silicone glue. The cell was then clamped in its holder. A $500 \mu \mathrm{L}$ standard buffer was taken into a $1 \mathrm{~mL}$ tuberculin syringe fitted with an $o$-ring in its metal plunger. The tuberculin syringe was attached into the syringe needle in the inlet port and the buffer was delivered into the cell. The OTTLE cell assembly was positioned on the diode array spectrophotometer sample compartment and a blank scan was taken. The cell assembly was removed from the compartment and the cell was glued to the clamp holder. The buffer was drawn out and the tuberculin syringe removed. Using a water aspirator, the OTTLE cell was dried by drawing air out of the inlet port for $15 \mathrm{~min}$. The thawed SiR-HP was degassed for 10 min using a vacuum pump. The degassed SiR-HP was taken into a $1 \mathrm{~mL}$ tuberculin syringe and delivered into the dried OTTLE cell. The $\mathrm{Ag} / \mathrm{AgCl}$ (saturated $\mathrm{KCl}$ ) reference electrode was inserted into the OTTLE cell overflow chamber. The entire set up was transferred to the diode array spectrophotometer sample compartment.

Journal of Electroanalytical Chemistry, Vol. 667-680, No. 15 (July 15, 2012): pg. 56-62. DOI. This article is (C) Elsevier and permission has been granted for this version to appear in e-Publications@Marquette. Elsevier does not grant permission for this article to be further copied/distributed or hosted elsewhere without the express permission from Elsevier. 
All matrix calculations, solution to the differential equations and factor analysis were carried out using MATLAB functions. The calculation of the fractional concentrations from the experimental absorbance data and molar absorptivities was done using the function FASTNNLS from the MATLAB add-on, PLS_TOOLBOX (Eigenvector, Inc.).

\section{Results and discussion}

\subsection{Spectroelectrochemistry of SiR-HP}

E. coli sulfite reductase hemoprotein $\left(\mathrm{SiR}-\mathrm{HP}^{0}\right)$ can be directly reduced at a methyl viologen modified gold electrode by two oneelectron steps. The reduction can be observed either voltammetrically or spectroscopically. A typical set of voltammograms have been shown in Ref. [6]. While a single wave was observed, two closely spaced oneelectron transfers would also give rise to a single wave. The voltammetric wave has an irreversible shape, indicating that the reduction occurs more readily than the re-oxidation.

Spectroelectrochemical data which will be described below will show that significant re-oxidation occurs voltammetrically. The two redox processes are described in Reactions (1) and (2).

The spectra for the three oxidation states of SiR-HP have been previously determined using spectroelectrochemistry and evolving factor analysis as shown in Ref. [19]. Using these spectra, the variation of the concentration of the three SiR-HP species as a function of potential was calculated for each scan rate [19]. The results for one scan rate are shown as points in Fig. 1 . The reductions of SiR-HP0 and $\mathrm{SiR}-\mathrm{HP}^{1-}$ are slower than expected for the Nernst equation, indicating a sluggish electron transfer.

From the data in Fig. 1, the current can be calculated from Fick's First Law:

$i_{1}=\frac{d q}{d t}=-F V \frac{d C_{1}}{d t}$

Journal of Electroanalytical Chemistry, Vol. 667-680, No. 15 (July 15, 2012): pg. 56-62. DOI. This article is (C) Elsevier and permission has been granted for this version to appear in e-Publications@Marquette. Elsevier does not grant permission for this article to be further copied/distributed or hosted elsewhere without the express permission from Elsevier. 
where $i_{1}$ is the current due to Reaction (1), $q_{1}$ is the charge that flows due to Reaction (1), $V$ is the volume of the cell, $F$ is Faraday's constant and $C_{1}=\left[\mathrm{SiR}-\mathrm{HP}^{0}\right]$. Similarly, the current due to Reaction (2) can be found from:

$$
i_{2}=\frac{d q_{2}}{d t}=F V \frac{d C_{3}}{d t}
$$

where $i_{2}$ is the current due to Reaction $(2), q_{2}$ is the charge that flows due to Reaction $(2)$, and $C_{3}=\left[\mathrm{SiR}-\mathrm{HP}^{2-}\right]$. The relationship between the current and [SiR-HP ${ }^{1-}$ ] is more complex due to the fact that it is produced in the first electron transfer and consumed in the second. The results of this calculation have been shown in Fig. 3 of Ref. [6] for one scan rate, along with the experimental data. The results show that this method can reproduce the shape of the voltammogram. The advantage of this method over analyzing the current directly is that the calculated current is free from background current and it is possible to examine each individual electron transfer separately.

\subsection{Identification of the redox mechanism}

Using the Butler-Volmer equation, the current can be related to kinetic parameters of the electron transfer process.

$$
\begin{aligned}
& \mathrm{i}_{1}=F A\left(\mathrm{k}_{\mathrm{f}, 1} \mathrm{C}_{1}-\mathrm{k}_{\mathrm{b}, 1} \mathrm{C}_{2}\right) \\
& \mathrm{i}_{2}=F A\left(\mathrm{k}_{\mathrm{f}, 2} \mathrm{C}_{2}-\mathrm{k}_{\mathrm{b}, 2} \mathrm{C}_{3}\right)
\end{aligned}
$$

where $C_{2}=$ [SiR-HP ${ }^{1-}$ ] $k_{f, 1}$ and $k_{f, 2}$ are the forward electron transfer rates for the 1 st and 2 nd electron transfer respectively, and $k_{b, 1}$ and $k_{b, 2}$ are the reverse electron transfer rates, similarly defined. Combining Eqs. (3) and (5), and Eqs. (4) and (6), we can obtain: 


$$
\begin{aligned}
& \frac{d C_{1}}{d t}=-\frac{1}{\delta}\left(k_{f, 1} C_{1}-k_{b, 1} C_{2}\right) \\
& \frac{d C_{3}}{d t}=-\frac{1}{\delta}\left(k_{f, 2} C_{2}-k_{b, 2} C_{3}\right)
\end{aligned}
$$

where $\delta=V / A$, and is equal to the cell thickness of the thin layer cell. From Butler-Volmer kinetics, the electron transfer rate constant, $k_{f}$ and $k_{b}$, can be related to the standard electron transfer rate constant, $k^{\circ}$, the electron transfer coefficient, $a$, and the standard potential, $E^{\circ}$ :

$\mathrm{k}_{\mathrm{f}}=\mathrm{k}^{\circ} \exp \left[-\alpha \mathrm{f}\left(\mathrm{E}-\mathrm{E}^{\circ}\right)\right]$

$\mathrm{k}_{\mathrm{b}}=\mathrm{k}^{\circ} \exp \left[(1-\alpha) \mathrm{f}\left(\mathrm{E}-\mathrm{E}^{\circ}\right)\right]$

where $f=F / R T$, the subscripts 1 and 2 can be added to $k^{\circ}, k_{f}, k_{b}, a$, and $E^{\circ}$ to indicate the first and second electron transfers, respectively. Combining Eqs. (7), (8), (9) and (10), we obtain:

$$
\begin{aligned}
& i_{1}=\frac{d C_{1}}{d t}=-\frac{k_{1}^{\circ}}{\delta}\left\{C_{1} \exp \left[-\alpha_{1} f\left(E-E_{1}^{\circ}\right)\right]-C_{2} \exp \left[\left(1-\alpha_{1}\right) f\left(E-E_{1}^{\circ}\right)\right]\right\} \\
& i_{2}=\frac{d C_{3}}{d t}=-\frac{k_{2}^{\circ}}{\delta}\left\{C_{2} \exp \left[-\alpha_{2} f\left(E-E_{2}^{\circ}\right)\right]-C_{3} \exp \left[\left(1-\alpha_{2}\right) f\left(E-E_{2}^{\circ}\right)\right]\right\}
\end{aligned}
$$

\subsection{Calculation of the electron transfer and homogeneous kinetic parameters}

Complete elucidation of the redox mechanism depends upon the correspondence between the calculated and experimental parameters over a range of scan rates. The concentrations as a function of time (potential) are given by the differential equations for the three SiR-HP concentrations species which are presented below:

Journal of Electroanalytical Chemistry, Vol. 667-680, No. 15 (July 15, 2012): pg. 56-62. DOI. This article is @ Elsevier and permission has been granted for this version to appear in e-Publications@Marquette. Elsevier does not grant permission for this article to be further copied/distributed or hosted elsewhere without the express permission from Elsevier. 


$$
\begin{aligned}
& \frac{d C_{1}}{d t}=-\frac{k_{1}^{\circ}}{\delta}\left\{C_{1} \exp \left[-\alpha_{1} f\left(E-E_{1}^{\circ}\right)\right]-C_{2} \exp \left[\left(1-\alpha_{1}\right) f\left(E-E_{1}^{\circ}\right)\right]\right\} \\
& \begin{array}{c}
\frac{d C_{2}}{d t}=\frac{k_{1}^{\circ}}{\delta}\left\{C_{1} \exp \left[-\alpha_{1} f\left(E-E_{1}^{\circ}\right)\right]-C_{2} \exp \left[\left(1-\alpha_{1}\right) f\left(E-E_{1}^{\circ}\right)\right]\right\} \\
\quad-\frac{k_{2}^{\circ}}{\delta}\left\{C_{2} \exp \left[-\alpha_{2} f\left(E-E_{2}^{\circ}\right)\right]-C_{3} \exp \left[\left(1-\alpha_{2}\right) f\left(E-E_{2}^{\circ}\right)\right]\right\} \\
\frac{d C_{3}}{d t}=\frac{k_{2}^{\circ}}{\delta}\left\{C_{2} \exp \left[-\alpha_{2} f\left(E-E_{2}^{\circ}\right)\right]-C_{3} \exp \left[\left(1-\alpha_{2}\right) f\left(E-E_{2}^{\circ}\right)\right]\right\}
\end{array}
\end{aligned}
$$

These differential equations can be solved using MATLAB differential equation function (ode23t). The cell thickness, $\delta$, can be calculated from the known molar absorptivity [16] and the concentration of SiR-HP in solution. The solutions to the equations above were then compared to the concentrations calculated from the spectroelectrochemical results at each scan rate. The electrochemical parameters were then manually adjusted to minimize the squares of the deviations between the calculated and measured concentrations of each species. The iteration was continued until no further improvements were obtained. The results are shown in Fig. 1 as lines for a scan rate of $0.30 \mathrm{mV} / \mathrm{s}$. In order to estimate the uncertainty and the sensitivity of the results to each parameter, once a minimum was found, each parameter was varied in both directions until the least squares deviations increased by $5 \%$. The results are shown in Table 1 , with the average percent deviations. The results were weakly dependent upon $a$, and an accurate estimation of the uncertainty was difficult to obtain at most scan rates. This procedure was repeated for all the scan rates studied ( Table 1). The redox potentials obtained with the voltammetry are consistent with the work of Siegel et al. The results are shown in Table 2 . There was good correspondence between the voltammetrically calculated values and values calculated previously using equilibrium methods for the redox potentials.

Journal of Electroanalytical Chemistry, Vol. 667-680, No. 15 (July 15, 2012): pg. 56-62. DOI. This article is @ Elsevier and permission has been granted for this version to appear in e-Publications@Marquette. Elsevier does not grant permission for this article to be further copied/distributed or hosted elsewhere without the express permission from Elsevier. 
The variation in the redox potentials calculated at each scan rate is generally within the experimental error of the calculations. The same was true for the $k^{\circ}$ values, except for the slowest scan rate where the $k^{\circ}$ values increased beyond the experimental error. In addition to electron transfer at the electrode surface, electron transfer can occur in solution via the disproportionation reaction below:

2SiR-HP1- $\rightarrow$ SiR-HP0 + SiR-HP2-

Inclusion of the disproportionation reaction had only modest effects on the overall fit. Marcus has predicted that the heterogeneous and homogeneous reactions are related [27]. As a result, a slow electron transfer at the surface should be reflected in a slow solution reaction. In addition, the equilibrium constant for Reaction (16) is less than unity in our case, minimizing its effect. The addition of the disproportionation reaction did not significantly affect the heterogeneous rate (within experimental error), nor did it explain the higher $k^{\circ}$ for the lowest scan rate. A marginally better fit was obtained for the highest scan rate $(2.3 \%$ vs. $2.4 \%)$. A comparison is shown in Fig. 2 with a $k_{\text {disp }}$ for Reaction (16) equal to $1.1 \mathrm{M}^{-1} \mathrm{~s}^{-1}$. The value of $k_{\text {disp }}$ should be considered an upper limit. Smaller effects were observed at lower scan rates. It is unclear why the $k^{\circ}$ values for the lowest scan rate are somewhat larger but it might be due to surface effects that are prominent at very low scan rates, small variations in the modified surface or variation in temperature.

The electron transfer rate for the siroheme reduction was found to be significantly slower than the rates for other heme proteins such as myoglobin or cytochrome $c$ ( Table 1). This is understandable because the siroheme in SiR-HP is less exposed to the surface and SiR-HP is a much larger protein than the other heme proteins studied. Another possible explanation is that the reduction of the siroheme leads to the concurrent loss of coordinated phosphate. The reorganization needed to facilitate ligand exchange would lead to slower electron transfer rates. Data to be presented in this work on the reduction of the cyanide coordinated SiR-HP complex will show that this ligand exchange does not significantly affect the electron transfer rate. There is little information available on the electron transfer rates

Journal of Electroanalytical Chemistry, Vol. 667-680, No. 15 (July 15, 2012): pg. 56-62. DOI. This article is (C) Elsevier and permission has been granted for this version to appear in e-Publications@Marquette. Elsevier does not grant permission for this article to be further copied/distributed or hosted elsewhere without the express permission from Elsevier. 
for $4 \mathrm{Fe}-4 \mathrm{~S}$ proteins. The electron transfer rate for the $4 \mathrm{Fe}-4 \mathrm{~S}$ cluster of SiR-HP is about an order of magnitude less than the $2 \mathrm{Fe}-2 \mathrm{~S}$ cluster in spinach ferredoxin, a much smaller protein.

Reversible electron transfers have been reported for other sulfite reductases [28] and ferredoxins [29] using square wave voltammetry. Lui and Cowan [28] studied two sulfite reductases containing siroheme and a 4Fe-4S cluster, and the redox potentials are given in Table 2 . The redox potentials for the siroheme and the 4Fe-4S cluster for their protein are considerably higher than $E$. coli sulfite reductase, indicating a substantially different protein environment. In addition, the siroheme and 4Fe-4S potentials are separated enough so that one redox cluster can be reduced separate from the other. These environmental differences may be the origin of the substantial difference in $k^{\circ}$ values between their proteins and ours. Interestingly, the $4 \mathrm{Fe}-4 \mathrm{~S}$ of the dissimilatory sulfite reductase of $D$. vulgaris (Hildenborough) did not reduce in the square wave voltammogram, but could be reduced coulometrically. This was ascribed to problems with the promotors $\left(\mathrm{Cr}\left(\mathrm{NH}_{3}\right)_{6}^{3+}\right)$, but might also be due to the fact that the electron transfer rate for the $4 \mathrm{Fe}-4 \mathrm{~S}$ cluster of this protein was similar to that for $E$. coli. In addition, the square wave voltammogram for the $4 \mathrm{Fe}-4 \mathrm{~S}$ cluster of the assimilatory protein was unusually narrow, indicating that the electron transfer process may be more complex than reported (complexity in the electron transfer mechanism often do not affect the redox potentials, the focus of that work).

Similarly, Smith and Feinberg [29] reported the reversible electron transfer for a number of $4 \mathrm{Fe}-4 \mathrm{~S}$ bacterial ferredoxins using square wave voltammetry. As with the previous work, the electron transfer rate was not the focus of their study. They clearly showed reversible Nernstian behavior for the reduction of the ferredoxins. Unfortunately, the presence of significant amounts of methyl viologen makes it difficult to separate heterogeneous electron transfer (at the electrode surface) from homogeneous electron transfer (via methyl viologen). Given the conditions of their experiment, this should not affect the redox potentials but will overestimate the electron transfer rates.

Journal of Electroanalytical Chemistry, Vol. 667-680, No. 15 (July 15, 2012): pg. 56-62. DOI. This article is (C) Elsevier and permission has been granted for this version to appear in e-Publications@Marquette. Elsevier does not grant permission for this article to be further copied/distributed or hosted elsewhere without the express permission from Elsevier. 
While there are many kinetic parameters to be determined in this mechanism, one can take advantage of the fact that certain scan rates and potentials are more sensitive to a given parameter. For example, the thermodynamic values, $E_{1}^{\circ}$ and $E_{2}^{\circ}$, can be measured most accurately at the slowest scan rates where the hysteresis due to slow electron transfer is the smallest. The kinetic parameters ( $k^{\circ} \mathrm{s}$ and $a$ 's) can be calculated at the higher scan rates. These parameters shifted in a predictable manner with scan rate as given by Eqs. (7) and (8).

The limitation of this method is the maintenance of thin-layer electrochemical behavior. The use of aqueous solutions minimizes the ohmic drop, which causes the concentration profile to grow from the edges to the center. For cell thicknesses around $100 \mu, 1 \mathrm{mV} / \mathrm{s}$ is a practical upper limit. Some effects of deviation from thin-layer conditions can be seen in the broader concentration profiles in Fig. 2. For faster scan rates, thinner cell thicknesses can be used, but the ohmic drop due to cell resistance will become dominant. This approach is most practical for situations where the redox potentials are close together. If $E_{2}^{\circ}<<E_{1}^{\circ}$, two separated waves can be observed, and the analysis can be easily done voltammetrically. If $E_{2}^{\circ}<<E_{1}^{\circ}$, there will not be significant concentrations of the intermediate to carry out the analysis of the individual electron transfers, and only the overall two electron processes can be analyzed. For biological systems, it has been to nature's advantage in many cases to have $E_{2}^{\circ} \approx E_{1}^{\circ}$, making this approach useful.

\subsection{Spectroelectrochemistry of SiR-HP-CN}

In the presence of cyanide, SiR-HP will form the cyanide complex. The spectroelectrochemistry of SiR-HP-CN is shown in Fig. 3 for a scan rate of $0.31 \mathrm{mV} / \mathrm{s}$. Using evolving factor analysis as described in Ref. [19] (see Supplemental Information, Fig. S1 and Table S1), it was found that up to four factors may be present in solution. The fourth factor appeared around $-0.73 \mathrm{~V}$. Three factors would correspond to the three oxidation states, and therefore it was necessary to determine if the fourth factor was real. Noise often leads to an overestimation of the number of factors. The data were solved first with three factors, and the concentrations that were calculated by

Journal of Electroanalytical Chemistry, Vol. 667-680, No. 15 (July 15, 2012): pg. 56-62. DOI. This article is (C) Elsevier and permission has been granted for this version to appear in e-Publications@Marquette. Elsevier does not grant permission for this article to be further copied/distributed or hosted elsewhere without the express permission from Elsevier. 
evolving window factor analysis. The spectra calculated from these three factors are shown in Fig. 4, and the concentrations are shown as points in Fig. 5. Excellent fits between the experimental and calculated spectra were obtained (see Supplemental Information, Figs. S2-S4). In addition, no significant deviations were seen between the experimental and calculated spectra in the region where the 4th factor was observed. The spectra obtained from factor analysis were also consistent with the spectra of Janick and Siegel [30]. Attempts to fit the data with four factors failed to produce meaningful results. The fourth factor probably represents small drift in the spectra with time, which was difficult to observe in the data, but factor analysis is very sensitive to these effects.

An examination of Fig. 5 shows that the reduction of the siroheme from the ferric to the ferrous state was shifted to more positive potentials, while the reduction of the $4 \mathrm{Fe}-4 \mathrm{~S}$ cluster was shifted to more negative potentials. This is consistent with what was previously observed [18]. The three redox states, corresponding to the three factors found in the spectra are shown below:

$\mathrm{SiR}^{3+, o x}-\mathrm{HP}-\mathrm{CN}+\mathrm{e}^{-} \rightarrow \mathrm{SiR}^{2+, o x}-\mathrm{HP}-\mathrm{CN}$

$\mathrm{SiR}^{2+, o x_{-}} \mathrm{HP}-\mathrm{CN}+\mathrm{e}^{-} \rightarrow \mathrm{SiR}^{2+, r e d}-\mathrm{HP}-\mathrm{CN}$

where $3+/ 2+$ refer to the siroheme oxidation state and ox/red refers to the oxidation state of the 4Fe-4S cluster. Using Eqs. (13), (14) and (15), the electrochemical parameters were calculated ( $E^{\circ}$ 's, $a^{\prime} \mathrm{s}$ and $k^{\circ} \mathrm{s}$ ) and the results are tabulated in Table 3 for each scan rate, along with the average deviations. The average values are summarized in Table 2.

A significant difference was observed for the E1० between our work and Siegel et al. [18], while the second redox potential (for the $4 \mathrm{Fe}-4 \mathrm{~S}$ cluster) that we obtained was consistent with the results of Siegel. The origin of the difference between our value for $E 1 \circ$ and Siegel's is not clear at this time. The visible spectra in both our cases are the same, indicating that we were studying the same species.

Journal of Electroanalytical Chemistry, Vol. 667-680, No. 15 (July 15, 2012): pg. 56-62. DOI. This article is (C) Elsevier and permission has been granted for this version to appear in e-Publications@Marquette. Elsevier does not grant permission for this article to be further copied/distributed or hosted elsewhere without the express permission from Elsevier. 
The electron transfer rates for the cyanide coordinated SiR-HP protein are comparable with the results for the protein without cyanide. The $k^{\circ}$ values for the cyanide coordinated protein are numerically smaller than the cyanide free complex, but the differences are within the experimental error. This is in spite of the loss of phosphate coordination during the first electron transfer. This indicates that protein reorganizational energy changes dominate over ligand exchange kinetics. As with the cyanide-free solutions, the $k^{\circ}$ values increased at the slowest scan rates, but there are insufficient data at this time to determine the source of this increase. For both complexes, the $k^{\circ}$ values for the $4 \mathrm{Fe}-4 \mathrm{~S}$ cluster are about a factor of two larger than the siroheme heterogeneous rate constant. The $4 \mathrm{Fe}-4 \mathrm{~S}$ cluster of SiR-HP is about $5.1 \AA$ from the solvent accessible surface and is completely sequestered, but direct cluster solvation is possible [32]. Little structural change was observed in $4 \mathrm{Fe}-4 \mathrm{~S}$ cluster upon reduction [32]. Thus, the reorganizational energy changes for the 4Fe-4S cluster are less than for the siroheme. Complete sequestering of the cluster from the solvent would slow down the electron transfer rate, while minimal structural changes would tend to speed up the electron transfer rate. These two competing factors are probably the reason that the electron transfer rate for the cluster in SiR-HP is comparable to spinach ferredoxin. More electron transfer data on $4 \mathrm{Fe}-4 \mathrm{~S}$ clusters are needed to fully evaluate this.

\section{Conclusions}

In this work, we were able to use spectroelectrochemical techniques to determine the electrochemical parameters for an $\mathrm{EE}$ mechanism. The ability to separate the currents due to each redox process makes the analysis of this mechanism considerably more straightforward. As was shown by others, the disproportionation reaction has limited effect on the analysis unless it is very fast. The effect of disproportionation depends strongly on the thermodynamics. In our case, the fact that the $\mathrm{E}^{\circ}$ values are similar means that the thermodynamic driving force is small. In addition, unlike the case of semi-infinite diffusion [31], the two-electron reduced product is not diffusing into a region with a high concentration of oxidized starting material.

Journal of Electroanalytical Chemistry, Vol. 667-680, No. 15 (July 15, 2012): pg. 56-62. DOI. This article is (C) Elsevier and permission has been granted for this version to appear in e-Publications@Marquette. Elsevier does not grant permission for this article to be further copied/distributed or hosted elsewhere without the express permission from Elsevier. 
In order to utilize this approach, it is necessary that the three oxidation states have distinct spectra. While it may be possible with additional information to use this approach if one of the species is colorless, it would be considerably more challenging. The use of factor analysis in order to deconvolute the three spectra provides additional power to this approach in that the individual spectra do not need to be known beforehand. In this work and previous work [19], evolving window factor analysis was used; other chemometric techniques would be equally applicable depending upon the nature of the data.

With one exception, the redox potentials measured by this technique agree well with the reported $E^{\circ}$ values. The electron transfer rates were slower than the values measured for smaller heme containing proteins. E. coli sulfite reductase hemoprotein is significantly larger than most heme proteins that have been studied voltammetrically. This is probably due to the inaccessibility of the siroheme and iron-sulfur group to the electrode surface, caused by their position in the protein and the protein's high molecular weight. In nature, the structure of the protein has evolved to maximize electron exchange rates. Heterogeneous exchange though may not be able to take advantage of these evolutionary changes. As a result, we see relatively slow electron transfer at the electrode surface.

Journal of Electroanalytical Chemistry, Vol. 667-680, No. 15 (July 15, 2012): pg. 56-62. DOI. This article is (C) Elsevier and permission has been granted for this version to appear in e-Publications@Marquette. Elsevier does not grant permission for this article to be further copied/distributed or hosted elsewhere without the express permission from Elsevier. 
NOT THE PUBLISHED VERSION; this is the author's final, peer-reviewed manuscript. The published version may be accessed by following the link in the citation at the bottom of the page.
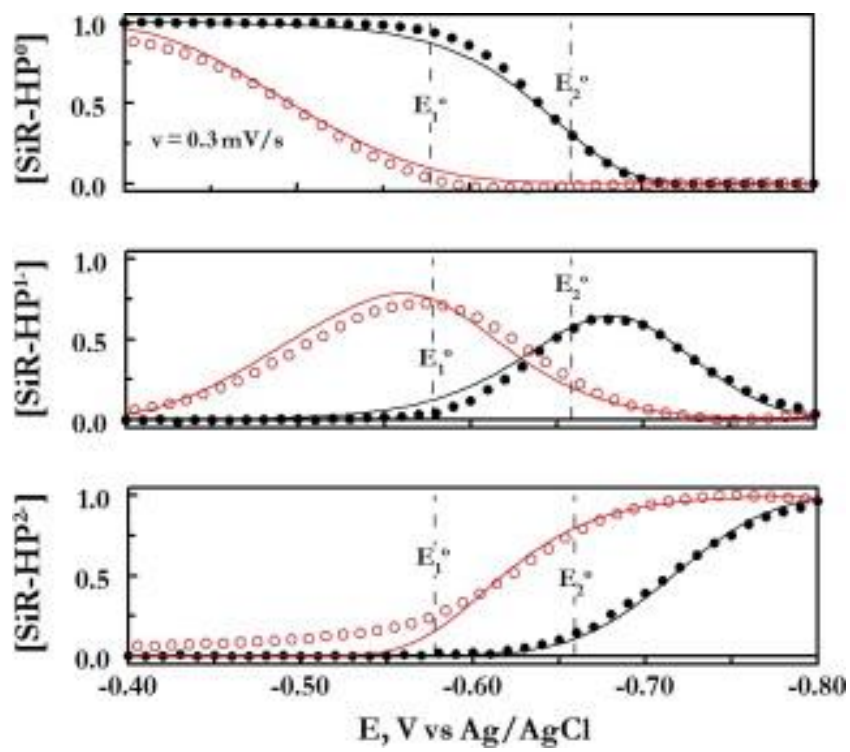

Fig. 1. Variation in the spectroelectrochemically calculated fractional concentrations of $\mathrm{SiRHP}^{0}, \mathrm{SiRHP}^{1-}$, and SiRHP ${ }^{2-}$. Lines are the calculated concentrations; circles are the experimental concentrations. Black corresponds to forward scan; red to reverse scan. Scan rate: $0.3 \mathrm{mV} / \mathrm{s}, 0.71 \mathrm{mM}$ SiR-HP, $0.10 \mathrm{M}$ phosphate buffer, $\mathrm{pH}=7.7$. temperature: $10^{\circ} \mathrm{C}$. Actual concentration $=$ fractional concentration $\times 0.71 \mathrm{mM}$. (For interpretation of the references to colour in this figure legend, the reader is referred to the web version of this article.)

Table 1. Voltammetric parameters obtained from spectroelectrochemical data of $E$. coli sulfite reductase hemoprotein at each scan rate.

\begin{tabular}{|c|c|c|c|c|c|}
\hline $\begin{array}{c}\text { Scan } \\
\text { rate } \\
(\mathrm{mV} / \mathrm{s})\end{array}$ & $\begin{array}{c}E_{1 E 1 \circ(m V}^{g} \\
\text { vs. NHE) }\end{array}$ & $\begin{array}{l}E_{2 \mathrm{E} 2 。}^{\square} \\
(\mathbf{m V})\end{array}$ & $k_{1 \mathrm{k} 1 \circ}^{\square}(\mathrm{cm} / \mathrm{s})$ & $k_{2 \mathbf{k} 2 \circ(\mathrm{cm} / \mathrm{s})}^{\circ}$ & $\begin{array}{c}\text { Average } \\
\text { deviation } \\
(\%)\end{array}$ \\
\hline 0.096 & $-357 \pm 4$ & $-381 \pm 5$ & $9 \pm 1 \times 10^{-6}$ & $2.1 \pm 0.6 \times 10^{-5}$ & 0.6 \\
\hline 0.30 & $-334 \pm 8$ & $-393 \pm 7$ & $4.2 \pm 0.7 \times 10^{-6}$ & $7 \pm 2 \times 10^{-6}$ & 1.3 \\
\hline 0.50 & $-339 \pm 8$ & $-370 \pm 8$ & $4.1 \pm 0.6 \times 10^{-6}$ & $8 \pm 2 \times 10^{-6}$ & 2.5 \\
\hline 0.70 & $-335 \pm 8$ & $-393 \pm 7$ & $4.3 \pm 0.7 \times 10^{-6}$ & $7 \pm 2 \times 10^{-6}$ & 2.1 \\
\hline 1.0 & $-337 \pm 11$ & $-409 \pm 7$ & $3.2 \pm 0.8 \times 10^{-6}$ & $6 \pm 3 \times 10^{-6}$ & 2.4 \\
\hline
\end{tabular}

Table 2. Electrochemical parameter obtained from the spectroelectrochemistry of $E$. coli sulfite reductase hemoprotein.

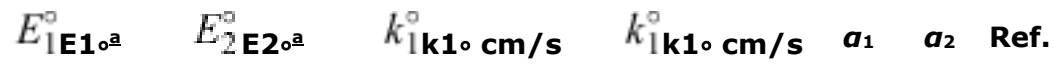

E. coli sulfite reductase hemoprotein $\underline{b}$

$$
-340 \pm 18-389 \pm 15 \quad 4.0 \pm 1.4 \times 10^{-6} \quad 7 \pm 2 \times 10^{-6} \quad 0.64 \quad 0.41 \quad \text { tw }
$$$$
\begin{array}{ll}
-340 & -405 \\
-333 & -406
\end{array}
$$

E. coli sulfite reductase hemoprotein $-319 \pm 12-498 \pm 14 \quad 1.9 \pm 1 \times 10^{-6} \quad 4 \pm 2 \times 10^{-6} \quad 0.68 \quad 0.45$ tw cyanide complex $\underline{b}$

Journal of Electroanalytical Chemistry, Vol. 667-680, No. 15 (July 15, 2012): pg. 56-62. DOI. This article is (c) Elsevier and permission has been granted for this version to appear in e-Publications@Marquette. Elsevier does not grant permission for this article to be further copied/distributed or hosted elsewhere without the express permission from Elsevier. 
NOT THE PUBLISHED VERSION; this is the author's final, peer-reviewed manuscript. The published version may be accessed by following the link in the citation at the bottom of the page.

\begin{tabular}{|c|c|c|c|c|c|c|c|}
\hline & 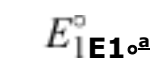 & $E_{2 \mathrm{E2} \text { 。a }}^{\Xi}$ & $k_{1 \mathbf{k} 1 \circ \mathrm{cm} / \mathrm{s}}^{\circ}$ & $k_{1 \mathbf{k} 1 \circ \mathrm{cm} / \mathbf{s}}^{\curvearrowleft}$ & $a_{1}$ & $a_{2}$ & Ref. \\
\hline & -155 & -490 & & & & & {$[18]$} \\
\hline \multirow[t]{2}{*}{ Myoglobin $\subseteq$} & & & $2.6 \times 10^{-5}$ & & 0.48 & & {$[10]$} \\
\hline & & & $5.4 \times 10^{-4}$ & & 0.5 & & [33] \\
\hline Cytochrome $c^{\underline{c}}$ & 260 & & $1.0 \times 10^{-3}$ & & 0.5 & & [34] \\
\hline Cytochrome $c^{\underline{d}}$ & 239 & & $7.2 \times 10^{-3}$ & & & & [35] \\
\hline 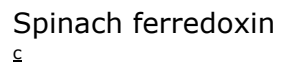 & -423 & & $6.5 \times 10^{-5}$ & & 0.60 & & 36] \\
\hline
\end{tabular}

D. vulgaris

(Hildenborough)

sulfite reductase

$-21 \quad-303$

[28]

(assimilatory)

D. vulgaris

(Hildenborough)

sulfite reductase

(dissimilatory)

tw $=$ This work.

a $\mathrm{mV}$ vs. NHE.

b $10^{\circ} \mathrm{C}, 0.096 \mathrm{mV} / \mathrm{s}$ Scan rate values omitted in average/standard deviation of $k^{\circ}$ values.

c $25^{\circ} \mathrm{C}$.

d $15{ }^{\circ} \mathrm{C}$.
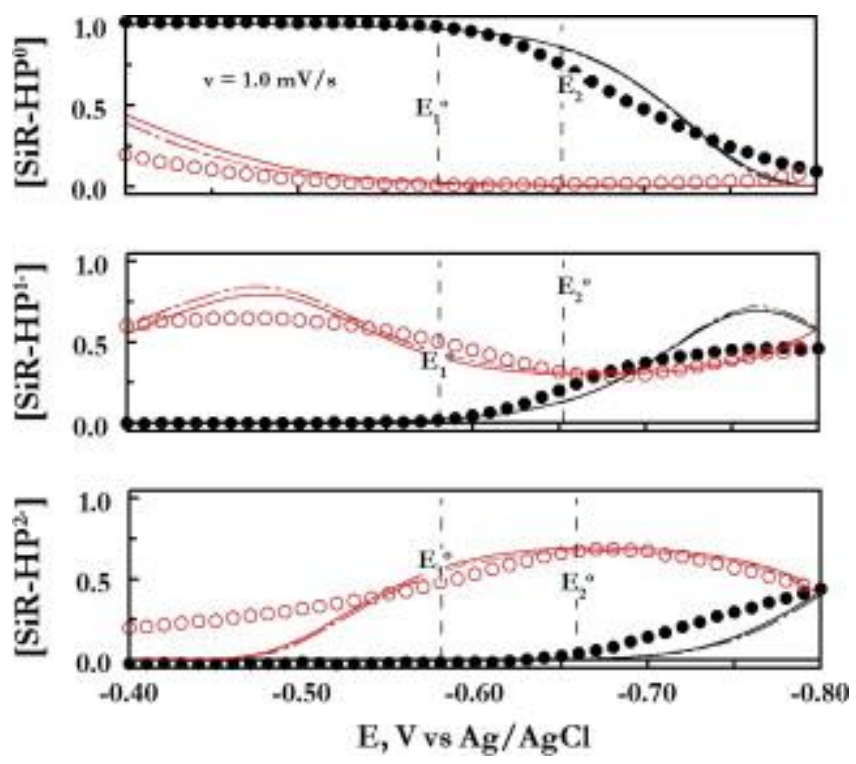

Fig. 2. Variation in the spectroelectrochemically calculated fractional concentrations of $\mathrm{SiRHP0}, \mathrm{SiRHP}^{1-}$, and SiRHP2-, as calculated without including the disproportionation reaction. Lines are the calculated concentrations without disproportionation; dash-dot lines are the calculated concentration with $k_{\text {disp }}=1.1 \mathrm{M}^{-1} \mathrm{~s}^{-1}$; circles are the experimental concentrations. Black corresponds to forward scan; red to reverse scan. Scan rate: $1.0 \mathrm{mV} / \mathrm{s}, 0.71 \mathrm{mM}$ SiR-HP, $0.10 \mathrm{M}$ phosphate buffer, $\mathrm{pH}=7.7$. temperature: $10^{\circ} \mathrm{C}$. Actual concentration $=$ fractional concentration $\times 0.71 \mathrm{mM}$. (For

Journal of Electroanalytical Chemistry, Vol. 667-680, No. 15 (July 15, 2012): pg. 56-62. DOI. This article is @ Elsevier and permission has been granted for this version to appear in e-Publications@Marquette. Elsevier does not grant permission for this article to be further copied/distributed or hosted elsewhere without the express permission from Elsevier. 
NOT THE PUBLISHED VERSION; this is the author's final, peer-reviewed manuscript. The published version may be accessed by following the link in the citation at the bottom of the page.

interpretation of the references to colour in this figure legend, the reader is referred to the web version of this article.)
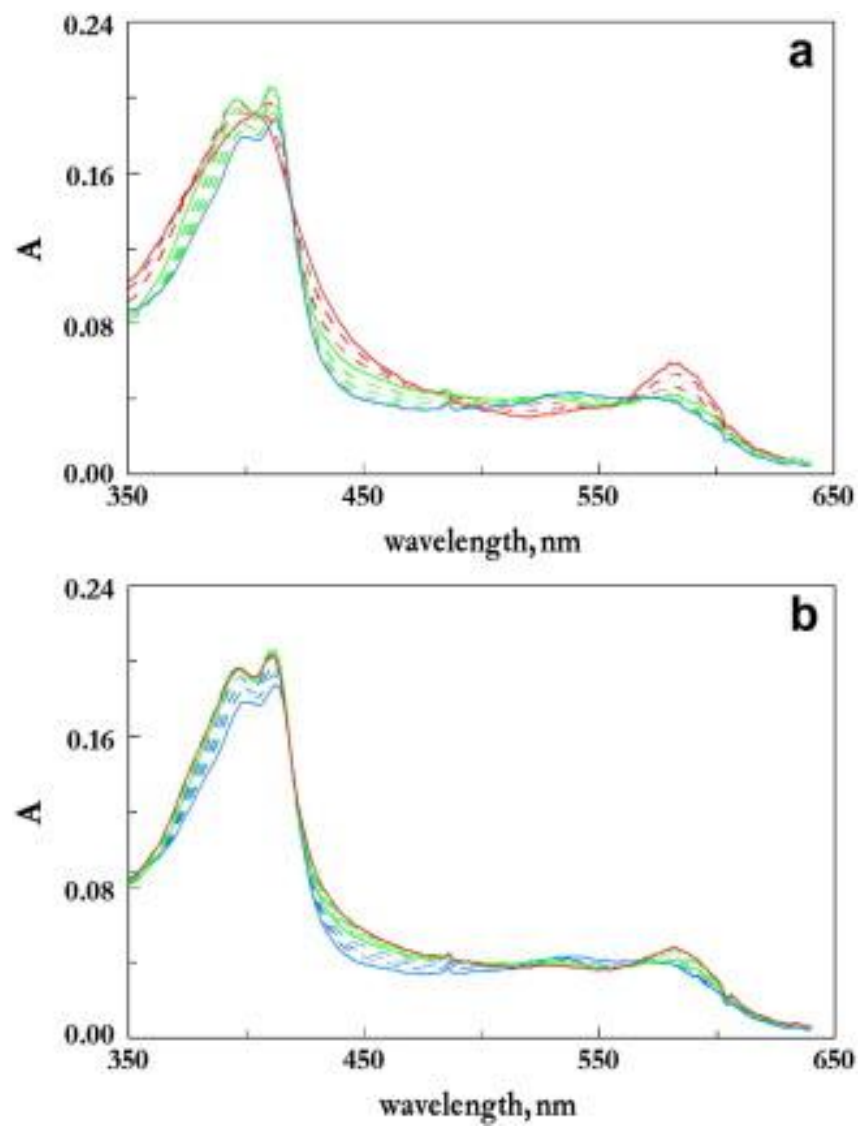

Fig. 3. Spectroelectrochemistry of $1.1 \mathrm{mM}$ SiR-HP-CN in $0.10 \mathrm{M}$ phosphate buffer. temperature $=10^{\circ} \mathrm{C}$. (a) blue line: $=-0.40 \mathrm{~V}$, red dashed lines: -0.632 and $-0.678 \mathrm{~V}$, solid green line: $-0.724 \mathrm{~V}$, green dashed lines: $-0.771,-0.817,-0.864 \mathrm{~V}$, solid blue line: $-0.899 \mathrm{~V}$ and (b) blue line: $-0.890 \mathrm{~V}$, dashed blue lines: -0.705 , $-0.658,-0.612 \mathrm{~V}$, solid green line: $-0.566 \mathrm{~V}$, dashed green lines: $-0.519,-0.473$, $-0.427 \mathrm{~V}$, solid red line: $-0.400 \mathrm{~V}$. Scan rate: $0.31 \mathrm{mV} / \mathrm{s}$. (For interpretation of the references to colour in this figure legend, the reader is referred to the web version of this article.) 
NOT THE PUBLISHED VERSION; this is the author's final, peer-reviewed manuscript. The published version may be accessed by following the link in the citation at the bottom of the page.

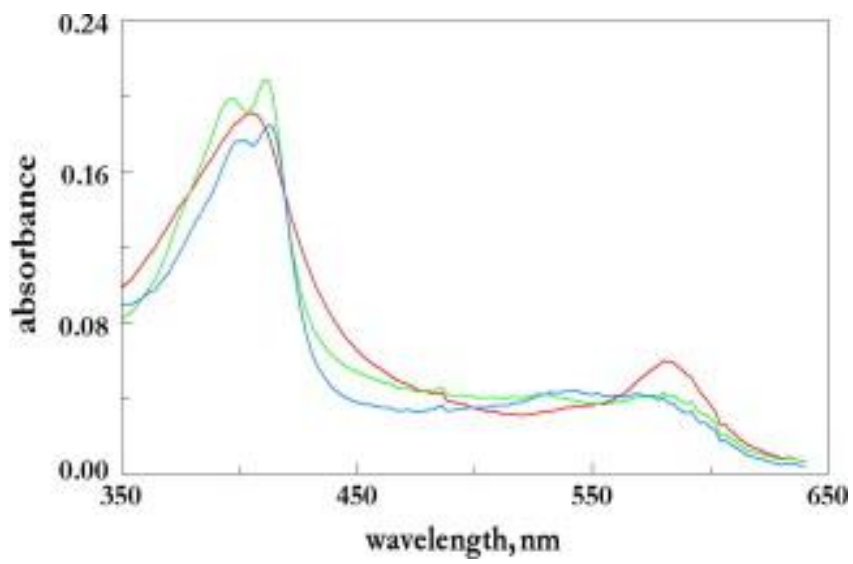

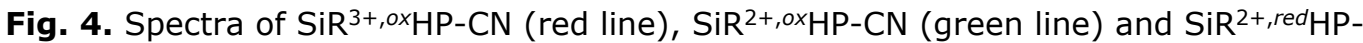
$\mathrm{CN}$ (blue line), as calculated using evolving factor analysis. (For interpretation of the references to colour in this figure legend, the reader is referred to the web version of this article.)
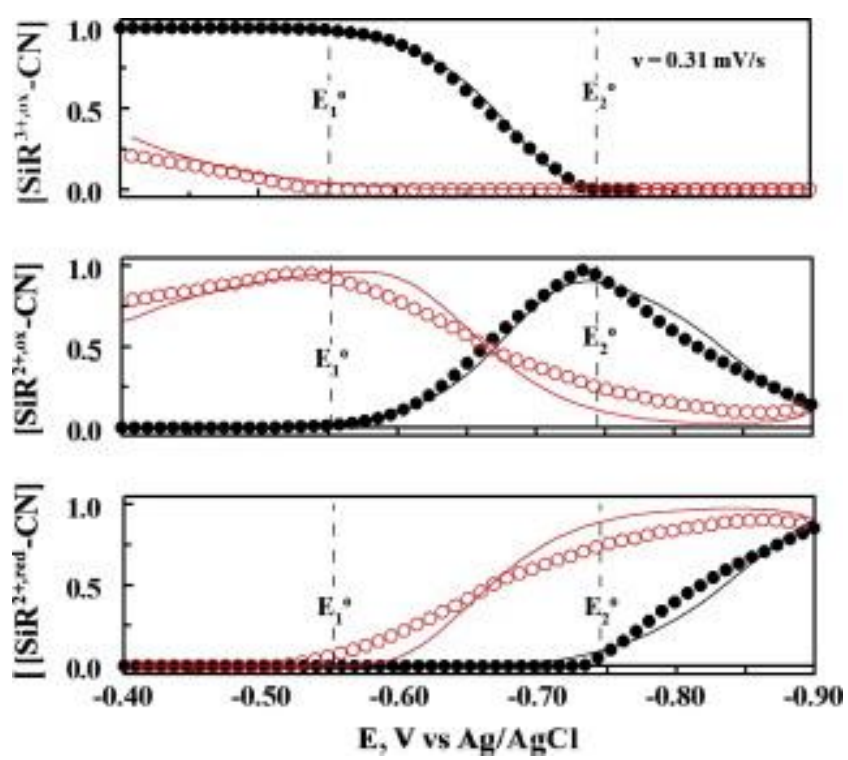

Fig. 5. Variation in the spectroelectrochemically calculated fractional concentrations of $\mathrm{SiR}^{3+, o x} \mathrm{HP}-\mathrm{CN}, \mathrm{SiR}^{2+, o x} \mathrm{HP}-\mathrm{CN}$, and $\mathrm{SiR}^{2+,}{ }^{2}{ }^{2} \mathrm{HP}-\mathrm{CN}$, as calculated without including the disproportionation reaction. Lines are the calculated concentrations; circles are the experimental concentrations. Black corresponds to forward scan; red to reverse scan. Scan rate: $0.31 \mathrm{mV} / \mathrm{s}, 1.1 \mathrm{mM}$ SiR-HP, $0.10 \mathrm{M}$ phosphate buffer, $\mathrm{pH}=7.7$. temperature: $10^{\circ} \mathrm{C}$. Actual concentration $=$ fractional concentration $\times 1.1 \mathrm{mM}$. 
Table 3. Voltammetric parameters obtained from spectroelectrochemical data of $E$. coli sulfite reductase hemoprotein-cyanide complex at each scan rate.

\begin{tabular}{|c|c|c|c|c|c|c|}
\hline $\begin{array}{c}\text { Scan } \\
\text { rate } \\
(\mathrm{mV} / \mathrm{s})\end{array}$ & $\begin{array}{c}E_{1 \mathrm{E} 1 。}^{\Xi} \\
\text { (mV vs. } \\
\text { NHE) }\end{array}$ & $\begin{array}{c}E_{2 \mathrm{E} 2}^{g} \\
(\mathbf{m V})\end{array}$ & $\Delta E(\mathrm{mv})$ & $k_{1 \mathbf{k} 1 。}^{g}(\mathrm{~cm} / \mathbf{s})$ & $k_{2 \mathrm{k} 2}^{g} \cdot(\mathrm{cm} / \mathrm{s})$ & $\begin{array}{c}\text { Average } \\
\text { deviation } \\
(\%)\end{array}$ \\
\hline$\sigma_{3}$ & $-352 \pm 8$ & $-512 \pm 9$ & $-160=$ & $3 \pm 1 \times 10^{-6}$ & reversibl & 1.5 \\
\hline 11 & $-304 \pm 8$ & $-480 \pm 8$ & $-176 \pm 11$ & $1.5 \pm 0.6 \times 10^{-6}$ & $4 \pm 2 \times 10^{-6}$ & 1.5 \\
\hline 0.31 & $-302 \pm 6$ & $-501 \pm 6$ & $-199 \pm 8$ & $1.2 \pm 0.2 \times 10^{-6}$ & $4.5 \pm 0.7 \times 10^{-6}$ & 1.0 \\
\hline
\end{tabular}

\section{References}

[1]D.H. Evans. Chem. Rev., 108 (2008), p. 2113

[2]E. Gileadi. J. Electroanal. Chem., 532 (2002), p. 181

[3] D.L. Langhus, G.S. Wilson. Anal. Chem., 51 (1979), p. 1139

[4] M.D. Ryan. J. Electrochem. Soc., 125 (1978), p. 547

[5] Y.C. Zhu, G.J. Cheng, S.J. Dong. J. Electrochem. Soc., 146 (1999), p. 3000

[6] M.D. Ryan, R.L. Keesey, Amierican Institute of Physics, Melville, NY, 2007 [27 September].

[7] E.E. Bancroft, J.S. Sidwell, H.N. Blount. Anal. Chem., 53 (1981), p. 1390

[8]E.E. Bancroft, H.N. Blount, F.M. Hawkridge. Biochem. Biophys. Res. Commun., 101 (1981), p. 1331

[9]D.J. Cohen, B.C. King, F.M. Hawkridge. J. Electroanal. Chem., 447 (1998), p. 53

[10]B.C. King, F.M. Hawkridge. J. Electroanal. Chem., 237 (1987), p. 81

[11] L. M. Siegel, P.S. Davis, H. Kamin. J. Biol. Chem., 249 (1974), p. 1572

[12] R.J. Krueger, L.M. Siegel. Biochemistry, 21 (1982), p. 2892

[13] L.M. Siegel, M.J. Murphy, H. Kamin. J. Biol. Chem., 248 (1973), p. 251

[14] L.M. Siegel, P.S. Davis. J. Biol. Chem., 249 (1974), p. 1587

[15] B.R. Crane, L.M. Siegel, E.D. Getzoff. Science, 270 (1995), p. 59

[16] P.A. Janick, L.M. Siegel. Biochemistry, 21 (1982), p. 3538

[17] P.A. Janick, D.C. Rueger, R.J. Krueger, M.J. Barber, L.M. Seigel. Biochemistry, 22 (1983), p. 396

[18] L.M. Siegel, D.C. Rueger, M.J. Barber, R.J. Krueger, N.R. Orme-Johnson, W.H. Orme-Johnson. J. Biol. Chem., 257 (1982), p. 6343

[19] R.L. Keesey, M.D. Ryan. Anal. Chem., 71 (1999), p. 1744

[20] M.D. Ryan, P.W. Crawford, in: Proceedings of the Fifth International Symposium on Redox Mechanisms and Interfacial Properties of Molecules of Biological Importance, The Electrochemical Society, Princeton, NJ, 1993.

[21]L. Krzeminski, L. Ndamba, G.W. Canters, T.J. Aartsma, S.D. Evans, L.J.C. Jeuken. J. Am. Chem. Soc., 133 (2011), p. 15085

Journal of Electroanalytical Chemistry, Vol. 667-680, No. 15 (July 15, 2012): pg. 56-62. DOI. This article is (C) Elsevier and permission has been granted for this version to appear in e-Publications@Marquette. Elsevier does not grant permission for this article to be further copied/distributed or hosted elsewhere without the express permission from Elsevier. 
[22] M. Pita, S. Shleev, T. Ruzgas, V.M. Fernandez, A.I. Yaropolov, L. Gorton. Electrochem. Commun., 8 (2006), p. 747

[23]A. Jain, G. Gazzola, A. Panzera, M. Zanoni, E. Marsili. Electrochim. Acta, 56 (2011), p. 10776

[24]E.J. Reijerse, M. Sommerhalter, P. Hellwig, A. Quentmeier, D. Rother, C. Laurich, E. Bothe, W. Lubitz, C.G. Friedrich. Biochemistry, 46 (2007), p. 7804

[25]S. Ghosh, A. Dey, Y. Sun, C.P. Scholes, E.I. Solomon. J. Am. Chem. Soc., 131 (2009), p. 277

[26]U. Swamy, M. Wang, J.N. Tripathy, S.K. Kim, M. Hirasawa, D.B. Knaff, J.P. Allen. Biochemistry, 44 (2005), p. 16054

[27] R.A. Marcus. J. Chem. Phys., 43 (1965), p. 679

[28]S.M. Liu, J.A. Cowan. J. Am. Chem. Soc., 116 (1994), p. 11538

[29]E.T. Smith, B.A. Feinberg. J. Biol. Chem., 265 (1990), p. 14371

[30] P.A. Janick, L.M. Siegel. Biochemistry, 22 (1983), p. 504

[31] J.W. Strojek, T. Kuwana, S.W. Feldberg. J. Am. Chem. Soc., 90 (1968), p. 1353

[32] B.R. Crane, L.M. Siegel, E.D. Getzoff. Biochemistry, 36 (1997), p. 12101

[33] B.C. King, F.M. Hawkridge, B.M. Hoffman. J. Am. Chem. Soc., 114 (1992), p. 10603

[34]E.F. Bowden, F.M. Hawkridge, J.F. Chiebowski, E.E. Bancroft, C. Thorpe, H.N. Blount. J. Am. Chem. Soc., 104 (1982), p. 7641

[35] K.B. Koller, F.M. Hawkridge. J. Am. Chem. Soc., 107 (1985), p. 7412

[36]C.D. Crawley, F.M. Hawkridge. Biochem. Biophys. Res. Commun., 99 (1981), p. 516

Corresponding author. Tel.: +1 414288 1625. Present address:

Eastern Connecticut State University, Department of Physical Sciences, Willimantic, CT 06226, United States.

Journal of Electroanalytical Chemistry, Vol. 667-680, No. 15 (July 15, 2012): pg. 56-62. DOI. This article is (C) Elsevier and permission has been granted for this version to appear in e-Publications@Marquette. Elsevier does not grant permission for this article to be further copied/distributed or hosted elsewhere without the express permission from Elsevier. 